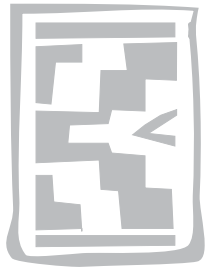

\title{
Intramammary antibiotics in dairy goats: effect of stage of lactation, parity and milk volume on withdrawal periods, and the effect of treatment on milk compositional quality
}

\author{
J. KARZIS ${ }^{1 *}$, E.F. DONKIN² and I.M. PETZER ${ }^{1}$
}

\begin{abstract}
KARZIS, J., DONKIN, E.F. \& PETZER, I.M. 2007 Intramammary antibiotics in dairy goats: effect of stage of lactation, parity and milk volume on withdrawal periods, and the effect of treatment on milk compositional quality. Onderstepoort Journal of Veterinary Research, 74:243-249

The length of the antibiotic withdrawal period after intramammary treatment was influenced by the milk yield of dairy goats during this trial. Shorter withdrawal periods were seen in relatively high yielding dairy goats (production above $1.5 \ell$ per day) compared to low producers (less than $1.3 \ell$ per day).

High yielding goats treated with Curaclox LC (Norbrook [Pharmacia AH]) had a withdrawal period of $42 \mathrm{~h}$, while low yielding goats, treated with the same product, had a withdrawal period of $74 \mathrm{~h}$. The recommended withdrawal period for Curaclox LC for use in cattle is $72 \mathrm{~h}$. Relatively high yielding goats treated with Rilexine 200 LC (Logos Agvet [Virbac]) had a significantly shorter withdrawal period $(37 \mathrm{~h})$ than that recommended for use in cattle $(96 \mathrm{~h})$. Low yielding goats treated with Spectrazol Milking Cow (Schering-Plough Animal Health) had a significantly longer (95 $\mathrm{h}$ ) withdrawal period than that recommended for use in cattle $(60 \mathrm{~h})$.

Withdrawal periods were also influenced by stage of lactation and parity. There was a moderate positive correlation between lactation number and withdrawal period, as measured by TRIS $\left(R^{2}=0.621\right)$, and a moderate negative correlation between stage of lactation and withdrawal period $\left(R^{2}=-0.669\right)$. In Trials 1, 2 and 3 combined there was a moderate negative correlation between withdrawal period and volume $\left(R^{2}=-0.511\right)$ and a strong positive correlation between withdrawal period and lactation number $\left(R^{2}=0.720\right)$.

The differences in percentage milk fat, protein and lactose before, during and after treatment were not statistically significant except in Trial 3 (Curaclox LC and Rilexine 200 LC) where protein and lactose differed significantly. In Trial 2 (Spectrazol Milking Cow) milk fat percentages differed significantly between treatment and control groups as did protein percentages in Trial 3. These differences are however, not biologically meaningful.
\end{abstract}

Keywords: Antibiotic withdrawal periods, dairy goats, lactose, milk fat, milk protein, milk yield, parity, stage of lactation

* Author to whom correspondence is to be directed. E-mail: jkarzis@mweb.co.za or joannejk@iafrica.com

1 Department of Production Animal Studies, Faculty of Veterinary Science, University of Pretoria, Private Bag X04, Onderstepoort, 0110 South Africa

2 Department of Animal and Wildlife Sciences, Faculty of Natural and Agricultural Sciences, University of Pretoria, 0002 South Africa

Accepted for publication 27 March 2007-Editor

\section{INTRODUCTION}

Milk yield, stage of lactation and parity of goats may influence the length of the withdrawal period of intramammary antibiotics from milk. These factors were investigated in goats after treatment with three intramammary antibiotic products. The effect of treatment on milk compositional quality (milk fat, total protein and lactose percentages) was investigated. 
The withdrawal period may be defined as the period that is required following the last medication in order to bring the concentration of the drug to below a tolerable value. The tolerable value of a drug depends on the Acceptable Daily Intake (ADI), which is based on pharmacological studies in experimental animals and is the lowest dose that is found to give some disorder, divided by a large safety factor. Parameters that have to be studied to establish the ADI value are:

- The ADI and the average amount of food taken by humans.

- The maximum residue level (MRL) permissible in foodstuffs of animal origin, such as meat or milk (Debackere 1995).

Many factors influence the elimination of antibiotics after intramammary application. These include the dose administered, the number of udder halves treated, the number of treatments, the milk yield, the condition of the udder, combination of treatments (e.g. anti-inflammatory and antibiotic) and the health status of the animal (Le Roux 2004).

Goat milk containing antibiotic residues cannot be used for human consumption as it poses a health hazard, more so due to its often use for food for babies, and it's affect on the production of cheese. The normal milk fat concentration of most European dairy goat breeds under cold environmental conditions is approximately $3.8 \%$, which is less than that for Nubians and Pygmy goats (Haenlein 2004).

The compositional quality of goat milk for different breeds is given in Table 1.

\section{MATERIALS AND METHODS}

\section{Herds used in trials}

Three trials were conducted. Trial 1 and Trial 2 were conducted at the Faculty of Veterinary Science, Uni- versity of Pretoria (Herd A), while Trial 3 was conducted on a commercial goat dairy in the Limpopo Province of South Africa (Herd B).

\section{Trial 1}

Herd A consisted of 15 lactating multiparous Saanen goats, all except one of which were in early lactation; the exception being in late lactation. For details see Karzis, Donkin \& Petzer 2007.

\section{Trial 2}

Trial 2 was conducted in Herd A using 14 lactating multiparous Saanen goats, all except one of which were in mid lactation. The exception was in late lactation. For details see Karzis et al. 2007.

\section{Trial 3}

Trial 3 was conducted in Herd B, using 64 Saanen, Saanen-Indigenous crossbreeds and Toggenburg goats, all of which were in mid lactation. Fifty-seven out of the 64 goats were in their first and the rest in their second lactation. For details see Karzis et al. 2007.

In all trials, results of clinical udder examinations, milk yield, parity and stage of lactation were considered and selection of experimental animals was done by the principle of pairing. For details see Karzis et al. 2007. Goats were considered to have a bacterial udder infection, when bacteria were isolated from the milk sample.

\section{Sampling during trials}

Goats were milked at 12 hourly intervals and foremilk samples were taken from udder halves of all goats for three milkings prior to the first intramammary treatment to establish baseline parameters (Karzis 2005). For details see (Karzis et al. 2007).

TABLE 1 Compositional quality of goat milk for different breeds

\begin{tabular}{|c|c|c|c|c|}
\hline Authors & Breed & $\begin{array}{l}\text { Milk fat } \% \\
\text { Mean } \pm \text { SE or SD }\end{array}$ & $\begin{array}{l}\text { Protein } \% \\
\text { Mean } \pm \text { SE or SD }\end{array}$ & $\begin{array}{l}\text { Lactose } \% \\
\text { Mean } \pm \text { SE }\end{array}$ \\
\hline Park 1991 & French Alpine and Anglo Nubian & $3.94 \pm 1.21(\mathrm{SD})$ & $3.51 \pm 0.77(\mathrm{SD})$ & ** \\
\hline Park \& Humphrey 1986 & Alpine and Nubian & $4.47 \pm 0.13(\mathrm{SE})$ & $3.42 \pm 0.05$ (SE) & ** \\
\hline Calderon et al. 1984 & French Alpine & $3.40 \pm 0.09(\mathrm{SE})$ & $3.30 \pm 0.06(\mathrm{SE})$ & ** \\
\hline Zeng \& Escobar 1996 & Alpine and Nubian & 4.08 * & $3.20^{*}$ & 4.41 \\
\hline
\end{tabular}

* Nubian goats produced a significantly higher $(P<0.05)$ percentage butterfat and protein than Alpine does in the same investigation

** Not given 
A composite milk sample from each udder half was taken before, during and after treatment to determine the percentage milk fat, protein and lactose.

\section{Antibiotic treatment}

In Trial 1, six untreated goats were used as controls, while eight goats were treated with Curaclox LC (Norbrook [Pharmacia AH]), 75 mg sodium ampicillin and $200 \mathrm{mg}$ sodium cloxacillin per dose. In Trial 2, seven goats were untreated controls and seven goats were treated, after each of three consecutive milkings at 12 hourly intervals, with Spectrazol Milking Cow (Schering-Plough Animal Health), $250 \mathrm{mg}$ cefuroxime per dose. Two products were investigated in Trial 3: Rilexine (SA) 200 LC (Logos Agvet [Virbac]), $100 \mathrm{mg}$ cephalexin, $100 \mathrm{mg}$ neomycin sulphate and $10 \mathrm{mg}$ prednisolone per dose, and Curaclox LC. Twenty untreated goats acted as controls and 20 goats were treated, after each of three consecutive milkings at 12 hourly intervals, with Rilexine (SA) 200 LC, while 12 goats were treated with Curaclox LC and 12 goats served as controls. For details see Karzis et al. 2007.

\section{Laboratory procedures}

\section{Thermo-resistant inhibitory substances}

The TRIS test was carried out on all milk samples to determine the presence of antibiotic residues and other heat stable inhibitory substances in the milk (Karzis 2005).

\section{Milk Oscan}

An accredited laboratory using a Milk Oscan System 4000 (The Rhine Ruhr Group) measured the percentage milk fat, total protein and lactose.

\section{Data management}

All data were entered and stored in Microsoft Excel and data were analysed statistically using the statistical programme GenStat (2003).
Pearson's coefficient measures the linear relationship between two random variates $(-1<r<1)$ (Draper \& Smith 1981). The tabled critical values for determining significance of a correlation coefficient are dependent on the pairs of data in the sample. Generally, a coefficient of about \pm 0.7 or more is regarded as indicating a fairly strong correlation while \pm 0.9 indicates a very strong correlation (Rayner 1969).

\section{RESULTS}

\section{Effects of yield, stage of lactation and parity on withdrawal periods}

Table 2 showed milk production levels and withdrawal periods as measured by TRIS for Curaclox LC, Spectrazol Milking Cow and Rilexine 200LC.

\section{Statistical analysis of milk fat, protein and lactose}

Table 3 showed milk fat percentages for treatment (T1, T2 and T3) and control groups of goats.

Table 4 showed protein percentages of milk treatment (T1, T2 and T3) and control groups of goats.

Table 5 showed lactose percentages of milk for treatment (T1, T2 and T3) and control groups of goats.

\section{DISCUSSION}

\section{Effects of milk yield, stage of lactation and parity on the length of withdrawal periods}

Goats used in Trial 1 and 2 had low milk yields while those used in Trial 3 were relatively high producers. There was a strong negative correlation $\left(R^{2}=0.701\right)$ between withdrawal period and milk yield after use of Curaclox LC in Trial 1 (Karzis 2005). This was possibly because of the dilution factor. A moderate negative correlation $\left(R^{2}=-0.493\right)$ was found between withdrawal period and milk yield in Trial 2

TABLE 2 Milk production levels and antibiotic withdrawal periods as measured by TRIS from Trials 1, 2 and 3

\begin{tabular}{|l|l|l|l|}
\hline Product & Trial & Production level & $\begin{array}{l}\text { Withdrawal periods } \pm \text { SD } \\
\text { (h) }\end{array}$ \\
\hline Spectrazol Milking Cow & Trial 2 & Low & $95 \pm 17.23$ \\
Curaclox LC & Trial 1 & Low & $74 \pm 19.21$ \\
Curaclox LC & Trials 1 and 3 & Low and high & $59 \pm 24.31$ \\
Curaclox LC & Trial 3 & High & $42 \pm 7.08$ \\
Rilexine 200 LC & Trial 3 & & $37 \pm 9.94$ \\
\hline
\end{tabular}


Intramammary antibiotics in dairy goats: effects

TABLE 3 Milk fat percentages for treatment (T1, T2 and T3) and control groups of goats. (Analysis of an unbalanced design)

\begin{tabular}{|l|l|l|l|l|l|l|}
\hline $\begin{array}{l}\text { Trial no. and } \\
\text { products used }\end{array}$ & $\begin{array}{l}\text { Treatment } \\
\text { groups }\end{array}$ & $\begin{array}{l}\text { Mean milk fat \% } \\
\text { at } \mathbf{( - 1 2 ~} \mathbf{~})+ \text { SD }\end{array}$ & $\begin{array}{l}\text { Mean milk fat \% } \\
\text { at (12 } \mathbf{~})+ \text { SD }\end{array}$ & $\begin{array}{l}\text { Mean milk fat \% } \\
\text { at (108 } \mathbf{~})+ \text { SD }\end{array}$ & $\begin{array}{l}\text { F probability } \\
\text { between } \\
\text { treatments }\end{array}$ & $\begin{array}{l}\text { F probability } \\
\text { interaction } \\
\text { between } \\
\text { treatments at } \\
\text { different times }\end{array}$ \\
\hline $\begin{array}{l}\text { Trial 1; } \\
\text { Curaclox LC }\end{array}$ & T1 & $4.29+1.52$ & $4.16+1.51$ & $4.07+1.41$ & $P=0.984$ & $P=0.729$ \\
\hline $\begin{array}{l}\text { Trial 2; } \\
\text { Spectrazol } \\
\text { Milking Cow }\end{array}$ & T2 & $4.56+0.63$ & $3.99+0.79$ & $3.99+0.46$ & & $P=0.566$ \\
\hline $\begin{array}{l}\text { Trial 3; } \\
\text { Curaclox LC } \\
\text { (T1) and }\end{array}$ & T1 & $3.83+1.05$ & $4.05+1.14$ & $3.55+0.67$ & $P=0.022$ & \\
$\begin{array}{l}\text { Rilexine 200 } \\
\text { LC (T3) }\end{array}$ & T3 & $3.48+0.62$ & $3.39+0.53$ & $3.28+0.78$ & & $P=0.199$ \\
\hline Trials 1 and 3 & C & $3.39+0.60$ & $3.85+0.52$ & $3.66+0.58$ & & \\
\hline
\end{tabular}

$P$ is significant at the $5 \%$ level $(P<0.05)$

TABLE 4 Protein percentages of milk for treatment (T1, T2 and T3) and control groups of goats. (Analysis of an unbalanced design)

\begin{tabular}{|c|c|c|c|c|c|c|}
\hline $\begin{array}{l}\text { Trial and } \\
\text { products used }\end{array}$ & $\begin{array}{l}\text { Treatment } \\
\text { groups }\end{array}$ & $\begin{array}{l}\text { Mean protein } \% \\
\text { at }(-12 \mathrm{~h}) \pm \text { SD }\end{array}$ & $\begin{array}{l}\text { Mean protein \% } \\
\text { at }(12 \mathrm{~h}) \pm \mathrm{SD}\end{array}$ & $\begin{array}{l}\text { Mean protein \% } \\
\text { at }(108 \mathrm{~h}) \pm \mathrm{SD}\end{array}$ & $\begin{array}{l}\text { F probability } \\
\text { between } \\
\text { treatments }\end{array}$ & $\begin{array}{l}\text { F probability } \\
\text { interaction } \\
\text { between } \\
\text { treatments at } \\
\text { different times }\end{array}$ \\
\hline $\begin{array}{l}\text { Trial 1; } \\
\text { Curaclox LC }\end{array}$ & $\begin{array}{l}\mathrm{T} 1 \\
\mathrm{C} 1\end{array}$ & $\begin{array}{l}3.35 \pm 0.59 \\
3.24 \pm 0.54\end{array}$ & $\begin{array}{l}3.21 \pm 0.44 \\
3.33 \pm 0.27\end{array}$ & $\begin{array}{l}3.17 \pm 0.40 \\
3.18 \pm 0.38\end{array}$ & $P=0.992$ & $P=0.701$ \\
\hline $\begin{array}{l}\text { Trial 2; } \\
\text { Spectrazol }\end{array}$ & $\begin{array}{l}\mathrm{T} 2 \\
\mathrm{C} 2\end{array}$ & $\begin{array}{l}3.07 \pm 0.64 \\
3.11 \pm 0.41\end{array}$ & $\begin{array}{l}3.04 \pm 0.44 \\
3.09 \pm 0.37\end{array}$ & $\begin{array}{l}3.04 \pm 0.49 \\
2.99 \pm 0.45\end{array}$ & $P=0.885$ & $P=0.973$ \\
\hline $\begin{array}{l}\text { Trial 3; } \\
\text { Curaclox LC } \\
\text { (T1) and } \\
\text { Rilexine (T3) }\end{array}$ & $\begin{array}{l}\text { C } \\
\text { T1 } \\
\text { T3 }\end{array}$ & $\begin{array}{l}3.13 \pm 0.21 \\
3.24 \pm 0.29 \\
3.30 \pm 0.25\end{array}$ & $\begin{array}{l}3.02 \pm 0.22 \\
3.29 \pm 0.23 \\
2.77 \pm 0.44\end{array}$ & $\begin{array}{l}3.09 \pm 0.23 \\
3.15 \pm 0.22 \\
3.34 \pm 0.98\end{array}$ & $P=0.054$ & $P<0.001$ \\
\hline $\begin{array}{l}\text { Trials } 1 \text { and 3; } \\
\text { Curaclox LC }\end{array}$ & $\begin{array}{l}\mathrm{C} \\
\mathrm{T} 1\end{array}$ & $\begin{array}{l}3.16 \pm 0.21 \\
3.31 \pm 0.50\end{array}$ & $\begin{array}{l}3.16 \pm 0.22 \\
3.25 \pm 0.38\end{array}$ & $\begin{array}{l}3.11 \pm 0.23 \\
3.16 \pm 0.34\end{array}$ & $P=0.069$ & $P=0.611$ \\
\hline
\end{tabular}

$P$ is significant at the $5 \%$ level $(P<0.05)$

after treatment with Spectrazol Milking Cow. However, no linear correlation was found between yield and withdrawal period in Trial 3 after treatment with both Curaclox LC and Rilexine 200 LC.

Withdrawal periods for Curaclox LC were shorter in Trial 3 with mostly high producing animals, than in Trial 1 or in Trial 1 and 3 combined, although there was no linear correlation between withdrawal period and yield. In Trials 1, 2 and 3 combined there was a moderate negative correlation between withdrawal period and yield $\left(R^{2}=-0.511\right)$. Treatment with Curaclox LC (Trial 1) and Spectrazol Milking Cow (Trial 2) did not affect the milk yield of the goats.
There was a moderate positive correlation between lactation number and withdrawal period $\left(R^{2}=0.621\right)$, a moderate negative correlation between stage of lactation and withdrawal period as measured by TRIS $\left(R^{2}=-0.669\right)$, and a moderate negative correlation between stage of lactation and lactation number in Trials 1 and 3 for Curaclox LC. The combined data of Trials 1, 2 and 3, however, showed a strong positive correlation between withdrawal period and lactation number $\left(R^{2}=0.720\right)$.

A weak negative linear correlation $\left(R^{2}=-0.373\right)$ was found between yield and lactation number in the combined data of Trials 1, 2 and 3 (Karzis 2005). 
TABLE 5 Lactose percentages of milk for treatment (T1, T2 and T3) and control groups of goats. (Analysis of an unbalanced design)

\begin{tabular}{|c|c|c|c|c|c|c|}
\hline $\begin{array}{l}\text { Trial and } \\
\text { products } \\
\text { used }\end{array}$ & $\begin{array}{l}\text { Treatment } \\
\text { groups }\end{array}$ & $\begin{array}{l}\text { Mean lactose \% } \\
\text { at }(-12 h)+\text { SD }\end{array}$ & $\begin{array}{l}\text { Mean lactose \% } \\
\text { at }(12 \mathrm{~h})+\mathrm{SD}\end{array}$ & $\begin{array}{l}\text { Mean lactose \% } \\
\text { at }(108 \mathrm{~h})+\text { SD }\end{array}$ & $\begin{array}{l}\text { F probability } \\
\text { between } \\
\text { treatments }\end{array}$ & $\begin{array}{l}\text { F probability } \\
\text { interaction } \\
\text { between } \\
\text { treatments at } \\
\text { different times }\end{array}$ \\
\hline $\begin{array}{l}\text { Trial 1; } \\
\text { Curaclox LC }\end{array}$ & $\begin{array}{l}\mathrm{T} 1 \\
\mathrm{C} 1\end{array}$ & $\begin{array}{l}4.32+0.94 \\
4.22+0.43\end{array}$ & $\begin{array}{l}4.32+0.41 \\
4.44+0.26\end{array}$ & $\begin{array}{l}4.52+0.27 \\
4.23+0.45\end{array}$ & $P=0.131$ & $P=0.156$ \\
\hline $\begin{array}{l}\text { Trial 2; } \\
\text { Spectrazol } \\
\text { Milking Cow }\end{array}$ & $\begin{array}{l}\mathrm{T} 2 \\
\mathrm{C} 2\end{array}$ & $\begin{array}{l}4.33+0.71 \\
4.19+0.64\end{array}$ & $\begin{array}{l}4.18+0.48 \\
4.25+0.49\end{array}$ & $\begin{array}{l}4.25+0.43 \\
4.03+0.56\end{array}$ & $P=0.426$ & $P=0.780$ \\
\hline $\begin{array}{l}\text { Trial 3; } \\
\text { Curaclox LC } \\
\text { (T1) and } \\
\text { Rilexine } 200 \\
\text { LC (T3) }\end{array}$ & $\begin{array}{l}\text { C } \\
\text { T1 } \\
\text { T3 }\end{array}$ & $\begin{array}{l}4.58+0.17 \\
4.69+0.22 \\
4.69+0.16\end{array}$ & $\begin{array}{l}4.57+0.22 \\
4.42+0.20 \\
4.48+0.18\end{array}$ & $\begin{array}{l}4.59+0.16 \\
4.60+0.28 \\
4.61+0.19\end{array}$ & $P=0.755$ & $P=0.001$ \\
\hline $\begin{array}{l}\text { Trials } 1 \text { and } 3 ; \\
\text { Curaclox LC }\end{array}$ & $\begin{array}{l}\mathrm{C} \\
\mathrm{T} 1\end{array}$ & $\begin{array}{l}4.48+0.31 \\
4.45+0.78\end{array}$ & $\begin{array}{l}4.51+0.24 \\
4.34+0.34\end{array}$ & $\begin{array}{l}4.48+0.32 \\
4.55+0.27\end{array}$ & $P=0.494$ & $P=0.474$ \\
\hline
\end{tabular}

$P$ is significant at the $5 \%$ level $(P<0.05)$

This was not the case in a study by Dulin, Paape, Schultze \& Weinland (1983) where milk yield increased with increasing lactation number.

Goats treated with Curaclox LC and Spectrazol Milking Cow in Trials 1 and 2 and which had bacterial udder infections had lower milk yields than goats without bacterial udder infections in Trials 1 and 2 . Goats with bacterial udder infections also showed longer withdrawal periods compared with non-infected goats in the same trials. However, this was not the case in the high and mid yielding goats in Trial 3 treated with Curaclox LC and Rilexine 200 LC. It was therefore evident that the presence of a bacterial udder infection decreased the milk yield in lowyielding goats but not in mid- and high-yielding goats.

\section{Analysis of milk fat, protein and lactose}

Milk fat, protein and lactose concentrations were measured three times during each Trial, prior to treatment, during treatment, and post treatment when antibiotic residues were no longer present in the milk.

\section{Milk fat}

In previous studies moderately strong positive correlations were present between percentage milk fat and percentage protein in goat milk and moderately negative correlations between percentage milk fat and electrical conductivity (Park \& Humphrey 1986; Park 1991). In this study, electrical conductivity measurements were taken, but due to the unreliability of the conductivity meters there was insufficient data for statistical analysis. The percentage milk fat, protein and lactose measured prior to treatment differed significantly between the Saanen goats used in Trials 1 and 2, and the Saanen-Toggenburg crossbreeds goats used in Trial 3 (Tables 3, 4 and 5). The milk fat percentage also depends on stage of lactation and diet (concentrate diet) according to Calderon, Peters, Smith \& Franke (1984) and Donkin, Boyazoglu, Els, Macgregor, Ramsay \& Lubout (2000).

No significant differences were found in the three trials between the milk fat percentage before, during and after treatment. No significant differences were found between the milk fat of goats in the treatment and control groups in Trials 1 and 3 and the combined data of Trials 1 and 3 for Curaclox LC treatment. In Trial 3 there was no significant difference between the treatments with Curaclox LC (T1) and Rilexine 200 LC (T3), and the control group (C) in the percentages of milk fat (Table 3 ). These results indicate that treatment with both Curaclox LC (T1) and Rilexine 200 LC (T3) did not influence the milk fat percentage. However, a significant difference ( $P=0.022)$ was found between treatment (T2) and control (C2) groups in Trial 2 in the percentage of milk fat where Spectrazol Milking Cow had been used (Table 3). This could have been due to the low production or the high fat content of the carrier substance of Spectrazol Milking Cow (a succinyllated fatty acid with triglycerides). 


\section{Milk protein}

The percentage of milk protein is known to differ between goat breeds (Table 1). A high concentrate diet has been found to cause milk fat to decrease and that it has no effect on milk protein or total solids (Calderon et al. 1984). Park (1991) found moderately strong negative correlations between the percentage protein and electrical conductivity (Park 1991). Donkin et al. (2000) reported that the percentage protein in Saanen and Saanen-Indigenous crossbred goats remains relatively stable in first and second lactations.

Milk protein percentage before, during and after treatment was found not to be significantly different in Trials 1 and 2 or with the combined data from Trials 1 and 3 after treatment with Curaclox LC. However, there is a significant difference $(P<0.001)$ between the percentage protein of treatment groups and between the three respective treatment times (Table 4).

The percentage of protein in milk from goats in the treatment and control groups showed no significant differences in Trial 1 (Table 4), showing that the treatment with Curaclox LC and Spectrazol Milking Cow did not influence the percentage protein in goat milk. Mean protein percentage of milk from goats between treatment (T1) and control (C) groups for Curaclox LC in Trials 1 and 3 are not significantly different (Table 4). However, protein percentage is significantly different $(P=0.054)$ between treatments (T1) using Curaclox LC, (T3) Rilexine 200 LC and control (C) goats in Trial 3 (Table 4). This difference might have been caused by nutritional changes on the commercial dairy farm.

\section{Lactose}

Donkin et al. (2000) found that the percentage lactose does not differ between goats in first and second lactations, but that it does differ between goats in their first lactation.

Lactose percentages of milk from goats were not significantly different in Trials 1 and 2 or from the combined data of Trials 1 and 3 after treatment with Curaclox LC. This was not the case for Trial 3 where there was a significant difference $(P=0.001)$ between the percentage lactose of milk from goats at the three respective treatment times (Table 5).

The percentage protein of milk from the goats did not differ significantly in Trials 1,2 and 3, or in the combined data of Trials 1 and 3 after treatment with Curaclox LC (Table 5). It seems therefore that the difference in the percentage lactose between the three respective treatment times seen in Trial 3 was not due to the treatment.

\section{CONCLUSION}

The lengths of withdrawal periods after intramammary antibiotic treatment were influenced by milk yield. Relatively high producers had a shorter withdrawal period than low producers treated with the same intramammary antibiotic. However, treatment with intramammary antibiotics as such did not affect the yield significantly. Future research on withdrawal periods of goat milk treated with intramammary antibiotics should take milk yield into account.

Withdrawal periods were also affected by stage of lactation and parity. In Trials 1, 2 and 3 and in combined data of Trials 1 and 3 after the use of Curaclox LC, withdrawal periods increased with increasing lactation number. Stage of lactation and parity should be taken into account in further studies on somatic cell counts (SCC) and withdrawal periods of intramammary antibiotics in goat milk.

The differences in percentage milk fat, protein and lactose before, during and after treatment were not statistically significant, except in Trial 3 where protein and lactose differed significantly. In Trial 2 (Spectrazol Milking (Cow) milk fat percentages differed significantly between treatment and control groups, as did protein percentages in Trial 3. These differences were, however, not biologically meaningful. Breed and stage of lactation of goats affected the percentages of milk fat, protein and lactose of goats. Further investigations are necessary to determine the effects of intramammary antibiotic treatment in different goat breeds and at different stages of lactation.

\section{ACKNOWLEDGEMENTS}

We thank the National Research Foundation for the funding of this research, Mr Tobie Fourie and the staff of the Limpopo Melkery and the staff of the Milk Laboratory, Onderstepoort and the Onderstepoort Teaching Animal Unit, Faculty of Veterinary Science for all their help, and Marie Smith of the Agricultural Research Council Silverton for the statistical analysis.

\section{REFERENCES}

CALDERON, I., DE PETERS, E.J., SMITH, N.E. \& FRANKE, A. A. 1984. Composition of goat's milk: Changes within and ef- 
fects of a high concentration diet. Journal of Dairy Science, 67:1905-1911.

DEBACKERE, M. 1995. Pharmacokinetics and pharmacodynamics of antimicrobials in relation to their residues in milk. Proceedings of the Symposium on Residues of Antimicrobial Drugs and other inhibitors in Milk, Kiel, Germany, 1995: 41.

DONKIN, E.F., BOYAZOGLU, P.A., ELS, H.C., MACGREGOR, R.G., RAMSAY, K.A. \& LUBOUT, P.C. 2000. Productivity of Saanen, South African indigenous and crossbred goats fed a complete feed: Preliminary results. Proceedings of the $7^{\text {th }}$ International Conference on Goats, France, 2000: 132-135.

DRAPER, N. \& SMITH, H. 1981. Applied regression analysis, $2^{\text {nd }}$ ed. New York: Wiley and Sons.

DULIN, A.M., PAAPE M.J., SCHULTZE, W.D. \& WEINLAND, B. T. 1983. Effect of parity, stage of lactation, and intramammary infection on concentration of somatic cells and cytoplasmic particles in goat milk. Journal of Dairy Science, 66: 2426-2433.

GenStat $₫$ for Windows $₫$ 2003. Introduction, edited by R.W. Payne, VSN International.

HAENLEIN, G.F.W. 2004. Goat milk in human nutrition. Small Ruminant Research 51:155-163.
KARZIS, J. 2005. Intramammary antibiotics in dairy goats: Withdrawal periods and tissue tolerance. M.Sc. thesis, University of Pretoria.

KARZIS, J., DONKIN, E.F. \& PETZER, I.M. 2007. Intramammary antibiotics in dairy goats: withdrawal periods of three intramammary antibiotics compared to recommended withdrawal periods for cattle. Onderstepoort Journal of Veterinary Research, 74:217-222.

LE ROUX, L. 2004. Antibiotika: Antibiotiese klassifikasie-kliniese gebruik van antimikrobiale middels (3), Livestock Health and Production Review, 6:5-9.

PARK, Y.W. 1991. Interrelationships between somatic cell counts, electrical conductivity, bacteria counts, percent fat and protein in goat milk. Small Ruminant Research, 5:367-375.

PARK, Y.W. \& HUMPHREY, R.D. 1986. Bacterial cell counts in goat milk and their correlations with somatic cell counts, percent fat and protein. Journal of Dairy Science, 69:32-37.

RAYNER, A.A. 1969. A first course in biometry for agriculture students. Pietermaritzburg: University of Natal Press.

ZENG, S.S. \& ESCOBAR, E.N. 1996. Effect of breed and milking method on somatic cell count, standard plate count and composition of goat milk. Small Ruminant Research, 19:169-175. 